\title{
ACIDIFICATION OF THE URINE AND INCREASED AMMONIUM EXCRETION WITHOUT CHANGE IN ACID-BASE EQUILIBRIUM : SODIUM REABSORPTION AS A STIMULUS TO THE ACIDIFYING PROCESS ${ }^{1,2}$
}

\author{
By WILLIAM B. SCHWARTZ, ROBERT L. JENSON, AND ARNOLD S. RELMAN \\ (From the Department of Medicine, Tufts College Medical School and the New England \\ Center Hospital; the Department of Medicine, Boston University School of Medicine \\ and the Evans Memorial, Massachusetts Memorial Hospitals, Boston, Mass.)
}

(Submitted for publication December 6, 1954 ; accepted December 29, 1954)

Acidification of the urine and excretion of ammonium are commonly thought to be regulated by the acidity of body fluids in such a manner that the kidneys in effect defend the normal $\mathrm{pH}$ of body fluids. Acidosis in blood or tissues is thought to increase excretion of acid and ammonium, and alkalosis to decrease it (1).

Data inconsistent with this view were first presented in 1923 by Hendrix and Sanders (2) who found that administration of alkaline sodium phosphate or sodium hippurate to fasting, slightly acidotic dogs increased the acidity of the urine and the excretion of ammonium, despite the fact that the blood bicarbonate concentration rose. In 1934, Briggs (3) observed that administration of sodium sulfate to dogs increased renal excretion of ammonium and decreased excretion of titratable alkali. Sodium sulfate produced similar but less striking changes in normal men. Although Briggs did not measure blood bicarbonate or $\mathrm{pH}$, and therefore did not rule out a slight acidosis due to dilution, he concluded that excretion of ammonium was a response to increased acidity of the urine and was independent of the acidity of the blood. $\mathrm{He}$ left unexplained the fundamental question, why infusion of a neutral salt like sodium sulfate or an alkaline substance such as dibasic phosphate should acidify the urine.

Pitts has adduced evidence that the urine is acidified by a process of ion exchange of sodium for hydrogen (4). Through this mechanism at least some part of sodium reabsorption is linked to the acidification of the urine. In the light of

1 This investigation was supported in part by grants from the National Institute of Arthritis and Metabolic Diseases and the National Heart Institute of the National Institutes of Health, United States Public Health Service.

2 Presented in part at the Annual Meeting of the American Physiological Society, April 13, 1954. this concept it was decided to ascertain whether, by varying the stimulus to sodium reabsorption, it would be possible to affect the acidity of the urine without first changing the acidity of the body fluids. The experiments to be described below answer this question affirmatively. They also suggest an explanation for the observations of Hendrix and Sanders, and of Briggs, as well as the more recent data which indicate that urine ammonium or acid excretion may be conditioned by factors other than body acidity $(5,6)$.

\section{METHODS}

The response to a standard alkaline sodium sulfate infusion was studied in fourteen experiments on nine healthy adult male subjects. Two groups of experiments were carried out with this standard infusion. In seven control studies subjects had been allowed to eat a normal diet prior to the morning of the experiment. On unmeasured, but presumably average, intakes of sodium, their urinary excretion of sodium in the control periods prior to infusion of sulfate ranged from 212 to 436 microequivalents per min. In the other seven studies, renal conservation of sodium had been induced prior to the experiment by one or more of several expedients aimed at promoting reabsorption of this ion. Four subjects had been on a low-sodium diet (approximately $10 \mathrm{mEq}$. sodium per day by calculation) for four to six days prior to the experiment, and had received 2 cc. of a mercurial diuretic on each of the first two days of the period of sodium restriction. Two of these subjects were also given $200 \mathrm{mgm}$. per day of compound $\mathrm{F}$ acetate by mouth in four equal doses on the day before, and the day of, the experiment. In order to stimulate sodium reabsorption without concomitant sodium depletion, the remaining three subjects were allowed a normal diet, but one was given desoxycorticosterone acetate (15 mgm. intramuscularly twice daily) and the other two were given compound $\mathrm{F}$ acetate $(300 \mathrm{mgm}$. daily by mouth in four equal doses) for a similar two-day period. As a result of these procedures, sodium excretion in the seven experimental subjects was markedly reduced during the urine collection periods prior to sulfate infusion. The sub- 
TABLE I

Control experiment-Experiment 7, E. F.-Normal diet

\begin{tabular}{|c|c|c|c|c|c|c|c|c|c|c|c|c|c|c|c|c|}
\hline \multirow[b]{2}{*}{$\underset{(\min .)}{\text { Time }}$} & \multicolumn{5}{|c|}{ Serum } & \multicolumn{11}{|c|}{ Urine } \\
\hline & $\begin{array}{c}\mathrm{pH} \\
\text { at } \\
37^{\circ} \mathrm{C} .\end{array}$ & $\underset{m M / L}{\mathrm{CO}_{2}}$ & $\underset{m E q . / L}{\mathrm{Na}}$ & $\underset{m E q . / L}{\mathbf{K}}$ & $\underset{m E q . / L}{\mathrm{Cl}}$ & $\underset{c c . / \min .}{\text { Flow }}$ & $\begin{array}{c}\mathrm{pH} \\
\text { at } \\
37^{\circ} \mathrm{C} .\end{array}$ & $\mathrm{NH}_{4}$ & TA & $\underset{\text { Micr }}{\mathrm{Na}}$ & $|\underset{\text { reEq./m}}{\mathbf{K}}|$ & min. & so، & $\mathrm{HCO}_{2}$ & $\underset{\substack{\text { micro- } \\
\text { Mol/min. }}}{\mathbf{P}}$ & $\begin{array}{c}\mathrm{Cc} \\
c c . / \mathrm{min}\end{array}$ \\
\hline $\begin{array}{r}0-30 \\
30-60\end{array}$ & $\begin{array}{l}7.37 \\
7.41\end{array}$ & $\begin{array}{l}29.0 \\
28.1\end{array}$ & $\begin{array}{l}142 \\
139\end{array}$ & 4.5 & 105 & $\begin{array}{r}5.1 \\
10.0\end{array}$ & $\begin{array}{l}6.42 \\
6.64\end{array}$ & $\begin{array}{l}38 \\
33\end{array}$ & $\begin{array}{l}5 \\
8\end{array}$ & $\begin{array}{l}236 \\
240\end{array}$ & $\begin{array}{l}120 \\
120\end{array}$ & $\begin{array}{l}326 \\
298\end{array}$ & & $\begin{array}{l}15 \\
39\end{array}$ & $\begin{array}{l}5 \\
4\end{array}$ & $\begin{array}{l}178 \\
147\end{array}$ \\
\hline $60-100$ & \multicolumn{16}{|c|}{ Infuse $1,000 \mathrm{cc}$. containing $190 \mathrm{mEq} . \mathrm{Na}_{2} \mathrm{SO}_{4}$ and $32 \mathrm{mEq} . \mathrm{NaHCO}_{3}$} \\
\hline $\begin{array}{c}60-90 \\
190-120 \\
120-150 \\
150-180 \\
180-210 \\
210-240\end{array}$ & 7.39 & 29.7 & 140 & 4.2 & 103 & $\begin{array}{l}7.9 \\
5.3 \\
5.3 \\
7.3 \\
9.1 \\
7.0\end{array}$ & $\begin{array}{l}6.87 \\
7.10 \\
6.73 \\
6.54 \\
6.52 \\
6.60\end{array}$ & $\begin{array}{l}27 \\
19 \\
29 \\
32 \\
32 \\
28\end{array}$ & $\begin{array}{l}5 \\
5 \\
5 \\
5 \\
7 \\
6\end{array}$ & $\begin{array}{r}539 \\
1,303 \\
850 \\
586 \\
480 \\
483\end{array}$ & $\begin{array}{r}173 \\
266 \\
190 \\
158 \\
122 \\
88\end{array}$ & \begin{tabular}{|r|}
242 \\
93 \\
84 \\
80 \\
87 \\
130
\end{tabular} & $\begin{array}{r}462 \\
1,405 \\
926 \\
654 \\
497 \\
421\end{array}$ & $\begin{array}{l}70 \\
29 \\
41 \\
30 \\
31 \\
32\end{array}$ & $\begin{array}{r}6 \\
11 \\
9 \\
7 \\
7 \\
7\end{array}$ & $\begin{array}{l}170 \\
157 \\
162 \\
160 \\
160 \\
167\end{array}$ \\
\hline
\end{tabular}

jects on low-sodium diets excreted 2 to 11 microequivalents per min. and those given only adrenal steroids excreted 60 to 79 microequivalents per min.

All experiments were carried out in the morning with the subjects fasting and supine. Water was taken by mouth at a rate of $100 \mathrm{cc}$. every half hour to insure adequate urine flows. At intervals of one-half hour the subjects voided directly into graduated cylinders partly filled with neutral mineral oil. Venous blood was drawn into oiled syringes at appropriate intervals.

After two or three control periods, one liter of approximately $0.2 \mathrm{~N}$ sodium sulfate solution was infused intravenously over a 30 to 40 -minute period. Thirty to thirtyfive $\mathrm{mEq}$. of sodium bicarbonate were added to each infusion in order to avoid any acidifying effect from dilution. Collections of urine and blood were continued for two and a half or three hours after the start of the infusion.

Concentrations of sodium, potassium, carbon dioxide, and chloride of serum, and $\mathrm{pH}$ of whole blood were measured. Urine specimens were analyzed for $\mathrm{pH}$, titratable acidity, ammonium, sodium, potassium, chloride, phosphate, and carbon dioxide. These methods have been described previously (7). In addition to these determinations all urine samples were analyzed for endogenous creatinine (8) and the specimens collected after the sulfate infusions were analyzed gravimetrically for sulfate (9). Urine bicarbonate was calculated from the $\mathrm{pH}$ and concentration of carbon dioxide, using the HendersonHasselbalch equation.

\section{RESULTS}

Typical experiments are shown in Tables I and II. The subject of Table I received a normal diet; the subject of Table II was taking a lowsodium diet and compound $\mathrm{F}$ acetate.

TABLE II

Sodium-retaining subject-Experiment 14, R. J.-Low-sodium diet, compound $F$ acetate

\begin{tabular}{|c|c|c|c|c|c|c|c|c|c|c|c|c|c|c|c|c|}
\hline \multirow[b]{2}{*}{$\underset{(\text { min. })}{\text { Time }}$} & \multicolumn{5}{|c|}{ Serum } & \multicolumn{11}{|c|}{ Urine } \\
\hline & $\begin{array}{c}\text { pH } \\
\text { at } \\
37^{\circ} \mathrm{C} .\end{array}$ & $\underset{m M / L}{\mathrm{CO}_{2}}$ & $\underset{m E q . / L}{\mathrm{Na}}$ & $\underset{m E q . / L}{\mathrm{~K}}$ & $\underset{m E q . / L}{\mathrm{Cl}}$ & $\underset{c c . / m i n}{\text { Flow }}$ & $\begin{array}{c}\mathrm{pH} \\
\text { at } \\
37^{\circ} \mathrm{C} .\end{array}$ & NH، & TA & $\mathbf{N a}$ & $\underset{\text { MicroE }}{\mathbf{K}}$ & $\underset{g . / m i}{\mathrm{Cl}}$ & SO، & HCO, & $\underset{\substack{\text { micro } \\
M o l / m i x .}}{\mathbf{P}}$ & $\underset{c c . / m i n .}{C o s}$ \\
\hline $\begin{array}{r}0-30 \\
30-60\end{array}$ & $\begin{array}{l}7.39 \\
7.43\end{array}$ & $\begin{array}{l}29.3 \\
29.7\end{array}$ & $\begin{array}{l}135 \\
135\end{array}$ & $\begin{array}{l}4.2 \\
4.4\end{array}$ & $\begin{array}{l}98 \\
97\end{array}$ & $\begin{array}{l}8.6 \\
6.5\end{array}$ & $\begin{array}{l}7.11 \\
7.10\end{array}$ & $\begin{array}{l}16 \\
12\end{array}$ & $\begin{array}{r}9 \\
12\end{array}$ & $\begin{array}{l}7 \\
5\end{array}$ & $\begin{array}{l}180 \\
149\end{array}$ & $\begin{array}{l}45 \\
26\end{array}$ & & $\begin{array}{r}109 \\
84\end{array}$ & $\begin{array}{r}11 \\
7\end{array}$ & $\begin{array}{l}132 \\
122\end{array}$ \\
\hline $60-100$ & \multicolumn{16}{|c|}{ Infuse $1,000 \mathrm{cc}$. containing $201 \mathrm{mEq} . \mathrm{Na}_{2} \mathrm{SO}_{4}$ and $34 \mathrm{mEq} . \mathrm{NaHCO}_{2}$} \\
\hline $\begin{array}{c}60-90 \\
90-120 \\
120-150 \\
150-180 \\
180-210 \\
210-240\end{array}$ & $\begin{array}{l}7.44 \\
7.41 \\
7.45\end{array}$ & $\begin{array}{l}28.7 \\
29.0 \\
30.9\end{array}$ & $\begin{array}{l}140 \\
137\end{array}$ & $\begin{array}{l}3.8 \\
3.3\end{array}$ & $\begin{array}{l}95 \\
97\end{array}$ & $\begin{array}{r}8.2 \\
10.2 \\
7.2 \\
5.7 \\
4.6 \\
3.7\end{array}$ & \begin{tabular}{|l|}
6.90 \\
6.34 \\
4.33 \\
4.31 \\
4.41 \\
4.48
\end{tabular} & $\begin{array}{l}17 \\
36 \\
61 \\
62 \\
61 \\
63\end{array}$ & \begin{tabular}{|r|}
5 \\
18 \\
30 \\
28 \\
29 \\
24
\end{tabular} & \begin{tabular}{|l|}
185 \\
816 \\
503 \\
280 \\
196 \\
149
\end{tabular} & \begin{tabular}{|l|}
377 \\
506 \\
384 \\
307 \\
277 \\
232
\end{tabular} & $\begin{array}{r}18 \\
6 \\
3 \\
<1 \\
<1 \\
<1 \\
\end{array}$ & \begin{tabular}{|r|}
457 \\
1,320 \\
968 \\
659 \\
539 \\
434
\end{tabular} & $\begin{array}{l}79 \\
33 \\
<1 \\
<1 \\
<1 \\
<1\end{array}$ & $\begin{array}{l}6 \\
5 \\
4 \\
6 \\
9\end{array}$ & $\begin{array}{l}138 \\
152 \\
148 \\
144 \\
146 \\
145\end{array}$ \\
\hline
\end{tabular}




\section{Changes in the serum}

Infusion of the mixture of sodium sulfate and sodium bicarbonate produced no significant change in blood $\mathrm{pH}$ or serum carbon dioxide content in either subject. Serum sodium and chloride also remained essentially unchanged. Potassium decreased sharply in the subject on the low-sodium diet (Table II), but decreased slightly, if at all, in the normal subject (Table I).

\section{Changes in the urine}

Infusion of approximately equal quantities of sulfate resulted in prompt and roughly equal excretion of the loading anion. The maximum excretion of sulfate was 1405 microequivalents per min. in the control subject and 1320 microequivalents per min. in the other. Total excretion of sulfate during the period of observation was 131 $\mathrm{mEq}$. in each instance. Chloride excretion fell off sharply. In the sodium-retaining subject chloride excretion, already very low in the pre-infusion periods, was virtually obliterated. Two other points of similarity were noted : a) in both subjects phosphate excretion was negligible and essentially unchanged, and $b$ ) endogenous creatinine clearances remained relatively stable throughout both experiments.

The significant differences between the control and experimental subjects occurred in the urine $\mathrm{pH}$ and in the excretion of bicarbonate, ammonium, sodium, and potassium:

a) Urine $\mathrm{pH}$ did not change significantly in the control subject (if anything, it may have risen slightly), but in the experimental subject there was a sharp drop in $\mathrm{pH}$ which reached a minimum of 4.3 in the second and third half-hour periods following completion of the infusion.

b) As might be expected from the striking differences in urine $\mathrm{pH}$, bicarbonate excretion did not change significantly in the control experiment, but in the other experiment it virtually ceased.

c) Ammonium excretion was essentially unaffected by the sulfate infusion in the control subject, but increased by a maximum of 49 microequivalents per min. in the experimental subject.

d) Sodium excretion was greatly augmented in both experiments, but the maximum increment was greater by 265 microequivalents per min. in the control subject. e) Potassium excretion was also significantly increased in both experiments, but the increment was greater in the experimental subject. In this particular experiment the increment in potassium excretion preceded by two periods the sharp fall in $\mathrm{pH}$ and rise in ammonium excretion.

\section{Differences between the urinary responses of the groups}

Urine $p H$ : Figure 1 illustrates the response of urine $\mathrm{pH}$ in both groups. The control subjects are represented by open circles and the experimental subjects by solid dots. It will be noted that the average urine $\mathrm{pH}$ in the periods prior to infusion of sulfate was in the same range (6.3 to 7.3) in both groups of subjects. The minimum $\mathrm{pH}$ after the infusion ranged between 6.0 and 6.8 in the seven control experiments; in five subjects the change in $\mathrm{pH}$ represented a slight decrease and in two subjects a slight increase. The urine $\mathrm{pH}$ in the experimental group always fell sharply, the minimum $\mathrm{pH}$ following the infusion ranging from

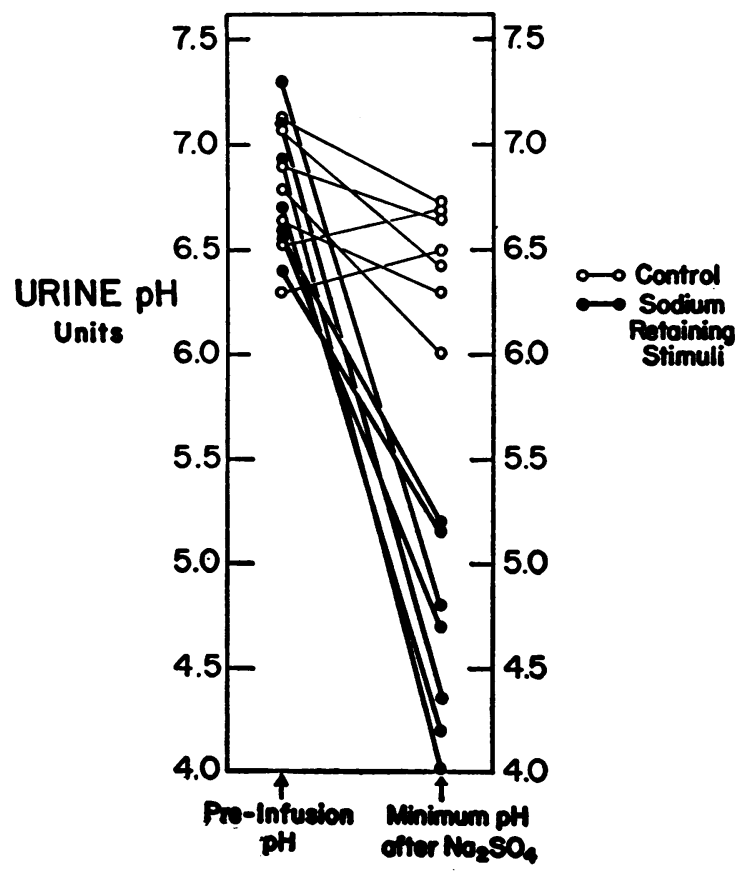

Fig. 1. The Efrect of Sodrum Sulfate Infusion on URINE PH

Values for urine $\mathrm{pH}$ in the pre-infusion period are comparable for both groups. Note that after sodium sulfate administration $\mathrm{pH}$ shows little or no change in the control group but drops to 5.2 or below in the experimental subjects. 
TABLE III

Total ammonium increment following infusion of sodium sulfate

\begin{tabular}{|c|c|c|c|}
\hline \multicolumn{2}{|c|}{ Control group } & \multicolumn{2}{|c|}{ Experimental group } \\
\hline Exp. No. & MicroEq. & Exp. No. & MicroEq. \\
\hline $\begin{array}{l}1 \\
2 \\
3 \\
4 \\
5 \\
6 \\
7\end{array}$ & $\begin{array}{r}1,380 \\
1,440 \\
780 \\
30 \\
2,130 \\
0 \\
0\end{array}$ & $\begin{array}{r}8 \\
9 \\
10 \\
11 \\
12 \\
13 \\
14\end{array}$ & $\begin{array}{l}4,290 \\
3,000 \\
2,430 \\
3,300 \\
5,610 \\
1,830 \\
5,010\end{array}$ \\
\hline $\begin{array}{l}\text { Mean } \\
\text { S.D. }\end{array}$ & $\begin{array}{l}823 \\
855\end{array}$ & & $\begin{array}{l}3,639 \\
1,381\end{array}$ \\
\hline
\end{tabular}

5.2 to 4.0. The four subjects on low-sodium diets had the most acid urines during the experimental periods and the lowest sodium excretions ( 2 to 11 microequivalents per min.) during the control periods; the other three subjects, who excreted 60 to 79 microequivalents per min. of sodium during control periods, had less acid urines. The acidifi-

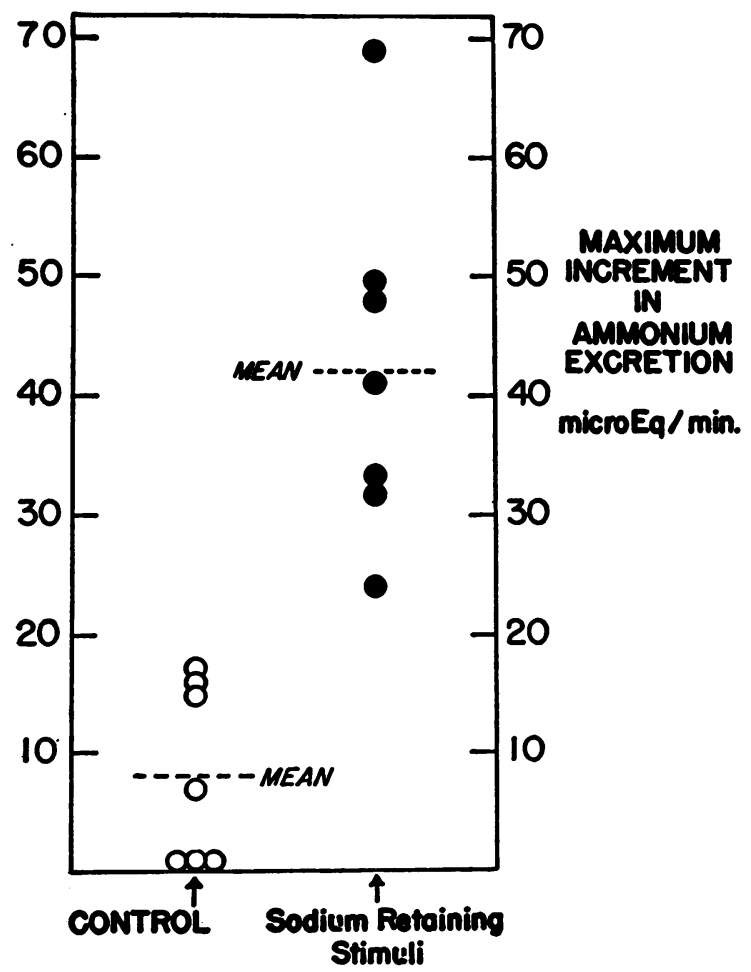

Fig. 2. The Effect of Sodium Sulfate Infusion on Urine Ammonium Excretion

Ammonium excretion in three control subjects did not change, and increased slightly in the other four. In the experimental group there was regularly a significant increment in ammonium output. cation of the urine in response to sulfate infusion, therefore, appeared to be dependent not only upon the existence, but also upon the intensity, of the tendency to reabsorb sodium.

Ammonium excretion: Table III presents the data on total cumulative increments in ammonium excretion for the first two-and-a-half hours after the start of the infusion. The mean increment in ammonium excretion in the control group was 823 microequivalents, and in the sodium-retaining group 3639 microequivalents. The difference between these means was highly significant $(\mathrm{p}<$ .01 ). Figure 2 illustrates the differences between the two groups with respect to the maximum increase in urine ammonium excretion produced by the sulfate infusion in a single period. The mean increment in the control group was 8 microequivalents per min. (range : 0 to 17 microequivalents per min.), while the mean increment in the experimental group was 42 microequivalents per min. (range : 24 to 69 microequivalents per min.). These differences, when tested statistically, are highly significant $(p<.01)$.

Potassium excretion: Table IV presents the data on total cumulative increments in potassium excretion for the five half-hour periods after the start of the infusion. The mean increment in total potassium excretion in the control group was 2618 microequivalents and in the sodium-retaining group 21,514 microequivalents. The difference between these means was highly significant $(\mathrm{p}<$ $.01)$.

Serum potassium decreased in approximate proportion to the magnitude of the potassium excretion in the urine. The largest reduction in concentration (1.1 mEq. per L.) was found in

TABLE IV

Total potassium increment following infusion of sodium sulfate

\begin{tabular}{|c|c|c|c|}
\hline \multicolumn{2}{|c|}{ Control group } & \multicolumn{2}{|c|}{ Experimental group } \\
\hline Exp. No. & MicroEq. & Exp. No. & MicroEq. \\
\hline $\begin{array}{l}1 \\
2 \\
3 \\
4 \\
5 \\
6 \\
7\end{array}$ & $\begin{array}{r}4,410 \\
1,560 \\
0 \\
0 \\
1,950 \\
1,110 \\
9,270\end{array}$ & $\begin{array}{r}8 \\
9 \\
10 \\
11 \\
12 \\
13 \\
14\end{array}$ & $\begin{array}{r}30,600 \\
21,120 \\
29,670 \\
19,080 \\
4,380 \\
15,150 \\
30,480\end{array}$ \\
\hline $\begin{array}{l}\text { Mean } \\
\text { S.D. }\end{array}$ & $\begin{array}{l}2,618 \\
3,294\end{array}$ & & $\begin{array}{r}21,497 \\
9,762\end{array}$ \\
\hline
\end{tabular}


the subject in Table II, who lost the greatest amount of potassium in his urine.

Titratable acid: While there appeared to be a slight increase in titratable acid in some of the experimental subjects (see Table II), the small amount of buffer (phosphate) present in the urine and the variations in its rate of excretion make the titratable acid data difficult to interpret. For this reason, no further comment on this subject will be made.

\section{DISCUSSION}

According to present concepts the urine is acidified, probably in the distal convoluted tubules, by a process involving exchange of sodium for hydrogen ions (4). Substitution of hydrogen for sodium converts bicarbonate in tubular fluid to carbonic acid and lowers the $\mathrm{pH}$. It also increases titratable acidity of the urine by an amount determined by the final $\mathrm{pH}$ and the quantity and $\mathrm{pK}$ of each of the buffer substances excreted in the urine.

Although acidification of the urine is widely believed to be a response to increased acidity of the blood or tissues, this hypothesis could not explain the results of the present experiments. Since all of the subjects received the same, slightly alkaline infusion, and since carbon dioxide and $\mathrm{pH}$ of serum did not change significantly in any of the subjects, it is not likely that the increased urine acidity following the infusion of sodium sulfate in the experimental subjects was the result of acidification of either extracellular or intracellular fluid. These experiments therefore indicate that the acidifying response to the sulfate load was conditioned by the tendency to retain sodium which existed prior to the administration of the load.

To explain how the state of sodium metabolism was responsible for the differences in urine acidity between the control and experimental groups, it is suggested that, in general, acidification of the urine will occur whenever there is a strong stimulus for increased reabsorption of sodium during the obligatory excretion of anion. Loading with the sodium salt of a relatively unreabsorbable anion like sulfate increases delivery of sodium and sulfate to the tubular site where the acidifying process of sodium-hydrogen exchange occurs. When there exists a strong stimulus for sodium reabsorption, such as that produced in the experiments reported here, the sodium sulfate load produces a sudden acceleration of the exchange process. That moiety of the sodium load reabsorbed without simultaneous reabsorption of anion obviously must be replaced in the tubular fluid by hydrogen or some other cation, such as potassium or ammonium.

The amount of hydrogen substituted for a given amount of reabsorbed sodium is probably limited by the amount of buffer substances (free ammonia and dibasic phosphate) available to "accept" the hydrogen, and by the limiting concentration of free hydrogen ions which can be achieved in tubular fluid. Since maximum acidity was achieved in those subjects in whom the stimulus for sodium reabsorption (as measured by the control sodium excretion) was strongest, ${ }^{3}$ it would seem that, under standard conditions of anion excretion, the intensity of the stimulus to sodium reabsorption influences the final urine $\mathrm{pH}$. Varying effects of sodium sulfate loads on urine $\mathrm{pH}$ reported by other workers $(11,12)$ are therefore probably explained by differences in the sodiumretaining tendencies of their subjects.

Differences in ammonium excretion between the control and experimental groups were striking (Figure 2, and Table III). It has been suggested that the acidity of the urine determines ammonium excretion $(3,4)$ and it is possible that the marked reduction in the urine $\mathrm{pH}$ in the experimental subjects was the immediate cause of their augmented ammonium output. Under standard conditions there tends to be an inverse relation between urine $\mathrm{pH}$ and ammonium excretion, but it is generally conceded that urine $\mathrm{pH}$ is not the sole determinant of ammonium excretion since the latter may vary independently of urine $\mathrm{pH}$ (4). Regardless of whether or not one believes that the ammonium excretion is the direct consequence of the increased urine acidity, the fact remains that in the present experiments the initiating stimulus to urine acidification and ammonium excretion must have been those factors which increased reabsorption of sodium in excess of anion, and they

\footnotetext{
8 While it is recognized that a small error may be introduced by the measurement of urine $\mathrm{pH}$ at room temperature, and the use of a correction factor of $.01 \mathrm{pH}$ units per degree Centigrade (10), it is nevertheless worthy of note that the minimum values observed in three experimental subjects were 4.3 or below. To our knowledge, acidity of this degree has not previously been reported in human subjects.
} 
apparently were not related to any change in acidity of body fluids. This conclusion does not exclude the possibility that there may also be other physiologic stimuli to ammonium excretion; nor should it obscure the probability that for any given stimulus the absolute magnitude of ammonium excretion may be modified by other factors, including the availability of amino acid substrate (13), the activity of tubular deaminating systems (14), and possibly the presence of other buffers in the urine.

Both groups of subjects excreted more potassium following the sulfate infusion but the mean cumulative potassium loss in the experimental group was considerably larger than in the control (Table IV). Regardless of whether the potassium which appears in the urine is secreted in exchange for reabsorbed sodium (15) or whether it represents filtered potassium which is not reabsorbed, the markedly increased potassium excretion in the experimental group was clearly related to the accelerated sodium reabsorption. The small potassium diuresis observed in most of the control subjects, as well as the occasional small increments in urine acidity and ammonium excretion, may have been due to slight increases in sodium reabsorption resulting from the sodium load
(16), although some non-specific effect of the sulfate ion, or the influence of diurnal variation cannot be ruled out.

Presumably the increment in potassium excretion constitutes another sodium-sparing mechanism, similar in this respect to the increased sodium-hydrogen exchange which resulted in augmented excretion of ammonium and increased urine acidity. Comparison of Tables III and IV shows that in these experiments potassium excretion is quantitatively more important as a sodiumconserving mechanism than is excretion of ammonium. The temporal relationships among these sodium-exchange processes are variable. In some experiments (e.g., Experiment No. 10, Figure 3) all three mechanisms appeared to be activated simultaneously in the first post-infusion period. In other experiments (e.g., Experiment No. 14, Table II) following the infusion there were one or more periods of potassium diuresis before the first sharp drop in urine $\mathrm{pH}$.

The relationship suggested here between sodium reabsorption and the excretion of ammonium, free hydrogen, and potassium would seem to explain many earlier observations, including those of Hendrix and Sanders (2), and Briggs

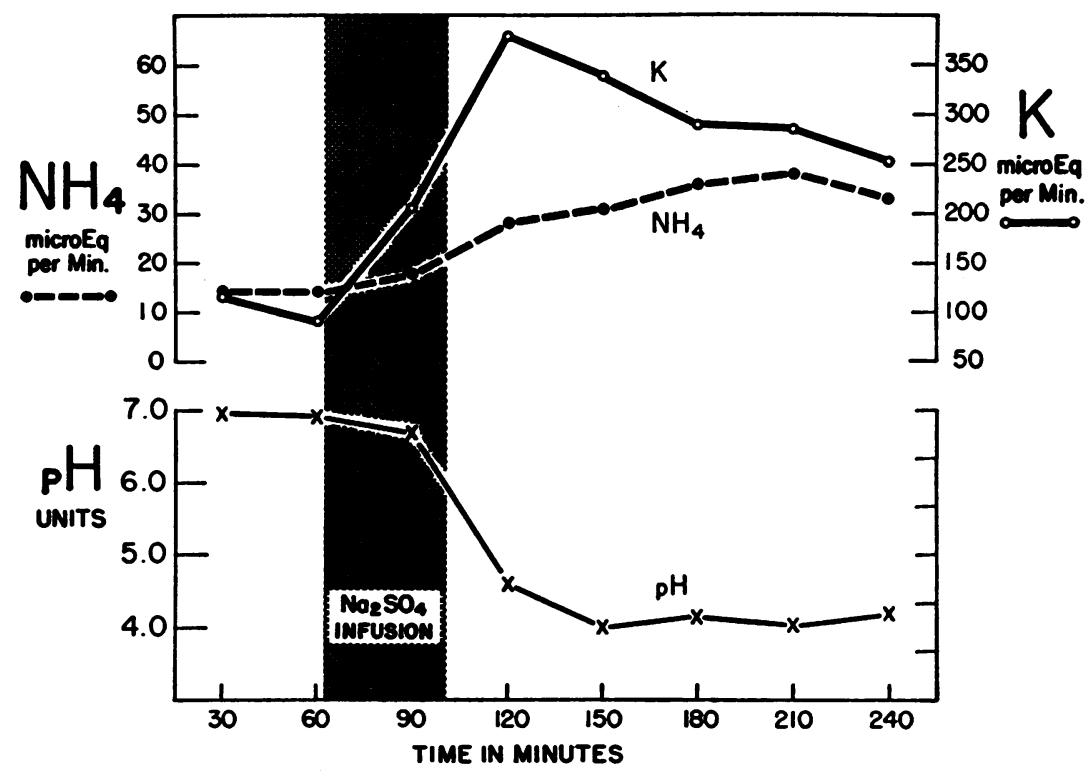

Fig. 3. Changrs in Excretion of Potassium and Ammonium, and in Urine pH, Produced by Infusion of Sodiux Sulfate in a Sodium-Retaining Subject (EXPERTMENT No. 10)

The shaded area denotes the period of infusion. Note that, following this, urine pH drops simultaneously with rise in potassium and ammonium excretion. 
(3). Renal conservation of body sodium requires tubular reabsorption of most of the filtered sodium under all circumstances. The tendency for sodium to be retained whenever its salts are administered probably explains why loading with rapidly excreted anions such as phosphate $(2,17)$, hippurate (2), para-aminohippurate (18), or sulfate (3) results in increased excretion of potassium, ammonium or acid. The contribution of titratable acid to the sodium-sparing process will depend upon the amount of urinary buffer available. Increasing the stimulus for sodium reabsorption will increase the activity of these mechanisms. Under these circumstances even sodium chloride loading might be expected to result in increased urine acidity and ammonium excretion, as was observed by Ryberg (19). Active stimulation of sodium reabsorption in excess of anion probably explains why prior depletion of sodium accelerates the renal ammonium and potassium responses to loading with acid salts, and why the magnitude of this response is not necessarily related to the degree of extracellular acidosis or to the quantity of acid retained in the body (6).

It may be postulated that the acute potassium diuresis in the sodium-retaining subjects resulted in loss of potassium from renal tubular cells and that this was a factor in the increased acidity of the urine (15). This possibility cannot be excluded in some experiments, but the occurrence in other experiments (Figure 3) of simultaneous increments in potassium, ammonium, and free hydrogen makes this hypothesis unlikely. Furthermore, the acidity of the urines in most of these experiments is much more marked than in any of those reported in clinical or experimental potassium depletion (20-22), even in cases where total potassium losses were far larger than those produced here.

A final point of interest is that the sulfate infusion tends to diminish chloride excretion in both groups of subjects but it affects bicarbonate in only the experimental group. If there is any competition among the inorganic ions for priority in reabsorptive transport (23), bicarbonate appears not to participate.

\section{SUMMARY AND CONCLUSIONS}

An alkaline infusion of sodium sulfate was administered rapidly to a control group of subjects and to subjects previously stimulated to retain sodium by sodium-free diets, adrenal steroids, or both. Although there were no significant changes in blood $\mathrm{pH}$ or $\mathrm{CO}_{2}$ content, the urine of the sodium-retaining group became intensely acid, ammonium excretion increased, and there was a striking increase in the excretion of potassium. Despite an equivalent excretion of sulfate, the control group showed no consistent or significant change in urine $\mathrm{pH}$ or ammonium excretion and only a small increment in potassium excretion.

It is concluded that a stimulus to reabsorb sodium without equivalent amounts of anion will result in acidification of the urine and increased ammonium and potassium excretion. This response does not require any prior change in acidity of blood or tissues. The degree of urine acidity achieved is approximately proportional to the intensity of the stimulus to sodium reabsorption.

\section{ACKNOWLEDGMENTS}

Invaluable technical assistance was rendered by Miss Jacquelyn Allen, Mrs. Marie Clark, Miss Helen Connors, Mr. Joseph Greaney, Miss Sonja Jeffress, Mrs. Mary Kimball, and Miss Arlene Roy.

\section{REFERENCES}

1. Smith, H. W., The Kidney: Structure and Function in Health and Disease. New York, Oxford University Press, 1951, Chap. XIII.

2. Hendrix, B. M., and Sanders, J. P., The effect of injections of sodium phosphates and sodium hippurate upon the excretion of acid and ammonia by the kidney. J. Biol. Chem., 1923, 58, 503.

3. Briggs, A. P., Excretion of ammonia and neutrality regulation. J. Biol. Chem., 1934, 104, 231 :

4. Pitts, R. F., Renal excretion of acid. Federation Proc., 1948, 7, 418.

5. Sartorius, O. W., Roemmelt, J. C., and Pitts, R. F., The renal regulation of acid-base balance in man. IV. The nature of the renal compensations in ammonium chloride acidosis. J. Clin. Invest., 1949, 28, 423.

6. Schwartz, W. B., Jenson, R. L., and Relman, A. S., The disposition of acid administered to sodium-depleted subjects: The renal response and the role of the whole body buffers. J. Clin. Invest., 1954, 33, 587.

7. Relman, A. S., and Schwartz, W. B., The effect of DOCA on electrolyte balance in normal man and its relation to sodium chloride intake. Yale $\mathrm{J}$. Biol. \& Med., 1952, 24, 540.

8. Hare, R. S., Endogenous creatinine in serum and urine. Proc. Soc. Exper. Biol. \& Med., 1950, 74, 148. 
9. Kolthoff, I. M., and Sandell, E. B., Textbook of Quantitative Inorganic Analysis, Rev. ed., New York, The Macmillan Co., 1943.

10. Kennedy, T. J., Jr., Orloff, J., and Berliner, R. W., Significance of carbon dioxide tension in urine. Am. J. Physiol., 1952, 169, 596.

11. Eggleton, M. G., Some factors affecting the acidity of urine in man. J. Physiol., 1947, 106, 456.

12. Wolf, A. V., and Ball, S. M., Effect of intravenous sodium sulfate on renal excretion in the dog. Am. J. Physiol., 1950, 160, 353.

13. Lotspeich, W. D., and Pitts, R. F., The rôle of amino acids in the renal tubular secretion of ammonia. J. Biol. Chem., 1947, 168, 611.

14. Davies, B. M. A., and Yudkin, J., Studies in biochemical adaptation. The origin of urinary ammonia as indicated by the effect of chronic acidosis and alkalosis on some renal enzymes in the rat. Biochem. J., 1952, 52, 407.

15. Berliner, R. W., Renal secretion of potassium and hydrogen ions. Federation Proc., 1952, 11, 695.

16. Black, D. A. K., Platt, R., and Stanbury, S. W., Regulation of sodium excretion in normal and salt-depleted subjects. Clin. Sc., 1950, 9, 205.

17. Schiess, W. A., Ayer, J. L., Lotspeich, W. D., and Pitts, R. F., The renal regulation of acid-base bal- ance in man. II. Factors affecting the excretion of titratable acid by the normal human subject. J. Clin. Invest., 1948, $27,57$.

18. Ingbar, S. H., Kass, E. H., Burnett, C. H., Relman, A. S., Burrows, B. A., and Sisson, J. H., The effects of ACTH and cortisone on the renal tubular transport of uric acid, phosphorus, and electrolytes in patients with normal renal and adrenal function. J. Lab. \& Clin. Med., 1951, 38, 533.

19. Ryberg, C., The importance of sodium ions for the excretion of ammonium and hydrogen ions in the urine. Acta physiol. Scandinav., 1948, 15, 161.

20. Kennedy, T. J., Jr., Winkley, J. H., and Dunning, M. F., Gastric alkalosis with hypokalemia. Am. J. Med., 1949, 6, 790.

21. Black, D. A. K., and Milne, M. D., Experimental potassium depletion in man. Clin. Sc., 1952, 11, 397.

22. Schwartz, W. B., and Relman, A. S., Metabolic and renal studies in chronic potassium depletion resulting from overuse of laxatives. J. Clin. Invest., 1953, 32, 258.

23. Rapoport, S., and West, C. D., Ionic antagonism: Effect of various anions on chloride excretion during osmotic diuresis in the dog. Am. J. Physiol., 1950, 162, 668. 